\title{
Occurrence of Euchaeta paraconcinna Fleminger, 1957 (Crustacea, Copepoda, Calanoida) in a coastal area of Bahia State, northeastern Brazil
}

\author{
Cristina de Oliveira Dias ${ }^{1}$ \& Sérgio Luiz Costa Bonecker ${ }^{2}$
}

Biota Neotropica v6 (n3) -http://www.biotaneotropica.org.br/v6n3/pt/abstract?article+bn02406032006

\author{
Date Received 08/10/2006 \\ Revised 09/20/2006 \\ Accepted 10/20/2006
}
Laboratório Integrado de Zooplâncton e Ictioplâncton, Departamento de Zoologia, Instituto de Biologia, Universidade Federal do Rio de Janeiro, CCS, Bloco A, Ilha do Fundão, CEP: 21941-590, Rio de Janeiro, RJ, Brasil
${ }^{1}$ Autor para correspondência: Cristina de Oliveira Dias crcldias@biologia.ufrj.br ${ }^{2}$ bonecker@biologia.ufrj.br

\begin{abstract}
Dias, C.O and Bonecker, S.L.C. Occurrence of Euchaeta paraconcinna Fleminger, 1957 (Crustacea, Copepoda, Calanoida) in a coastal area of Bahia State, northeastern Brazil. Biota Neotrop. Sep/Dec 2006 vol. 6, no. 3 http:// www.biotaneotropica.org.br/v6n3/pt/abstract?article+bn02406032006 ISSN 1676-0611
\end{abstract}

The calanoid copepod Euchaeta paraconcinna Fleminger, 1957 is reported from Camamu Bay, state of Bahia, northeastern Brazil (1402'49"S; 38 52'58"W). Three females were collected by vertical hauls with a plankton net of $200 \mu \mathrm{m}$ mesh size. This is a new record for this species in northeastern Brazil.

Key words: Copepoda, new occurrence, Euchaeta paraconcinna, Southwest Atlantic

\section{Resumo}

Dias, C.O and Bonecker, S.L.C. Ocorrência de Euchaeta paraconcinna Fleminger, 1957 (Crustacea, Copepoda, Calanoida) em uma região costeira do estado da Bahia, Nordeste do Brasil. Biota Neotrop. Sep/Dec 2006 vol. 6, no. 3 http:// www.biotaneotropica.org.br/v6n3/pt/abstract?article+bn02406032006 ISSN 1676-0611

Uma nova ocorrência para o copépode Calanoida Euchaeta paraconcinna Fleminger, 1957 foi registrada na região costeira da baía de Camamu, estado da Bahia, Nordeste do Brasil (1402'49"S; 3852'58"W). Três fêmeas foram coletadas em arrastos verticais, com rede de plâncton, de $200 \mu \mathrm{m}$ de malha. Este registro revela uma nova ocorrência desta espécie no Nordeste do Brasil.

Palavras-chave: Copepoda, nova ocorrência, Euchaeta paraconcinna, Atlântico sudoeste

http://www.biotaneotropica.org.br 


\section{Introduction}

Euchaeta paraconcinna Fleminger, 1957 was originally described from specimens obtained in Onslow Bay, North Carolina, and the Gulf of Mexico, and has subsequently been recorded from the Gulf of Guinea along the coast from Sierra Leone to Angola (Vervoort 1963) and the Caribbean Sea (Park 1975). In Brazil, the only citation of this species is from northern Brazil, by Yoneda (1999). Montú \& Gloeden (1998) did not include this record in their revision of the Calanoida. Data on the biology of $\boldsymbol{E}$. paraconcinna indicate its tropical-subtropical distribution and mesopelagic habit (Bradford-Grieve et al. 1999, LópezSalgado et al. 2000). This study reports the occurrence of E. paraconcinna in a coastal area of northeastern Brazil (Camamu, state of Bahia).

\section{Material and Methods}

The biological material examined was obtained as part of a project to study the copepod fauna off northeastern Brazil. The zooplankton program was carried out at several sites along the coast of Bahia, during January and August 2004. The sites were located between Garapuá (134' $S$; $\left.38^{\circ} 91^{\prime} \mathrm{W}\right)$ and the Maraú peninsula $\left(14^{\circ} 10^{\prime} \mathrm{S} ; 39^{\circ} \mathrm{W}\right)$ in the adjacent internal shelf near Camamu Bay, at stations shallower than $50 \mathrm{~m}$.
The zooplankton samples were collected during the day, by vertical hauls with a conical net of mesh size $200 \mu \mathrm{m}$ and mouth diameter $60 \mathrm{~cm}$, fitted with a calibrated flowmeter. Samples were preserved in $4 \%$ buffered formalin. Sampling was carried out from August 26 to 28, 2004. The sample that contained $\boldsymbol{E}$. paraconcinna was taken at $30 \mathrm{~m}$ depth (1402'49"S; 38'52'58"W).

\section{Results and Discussion}

The specimens were collected during the dry season; water temperature was $26.3^{\circ} \mathrm{C}$ at the surface and $25.1^{\circ} \mathrm{C}$ near the bottom. Salinity was 35.3 at the surface and 35.9 near the bottom.

A total of three female copepods (2 ovigerous females) belonging to the species $\boldsymbol{E}$. paraconcinna were collected. Their total body lengths were 2.65 to $2.84 \mathrm{~mm}$, measured in dorsal view from the anterior end of the cephalic somite to the posterior margin of the anal somite. The total length of the specimens is larger than reported by Park (1995), who found specimens with lengths from 2.38 to $2.56 \mathrm{~mm}$.

The continental shelf off the state of Bahia, on the northeastern coast of Brazil, is one of the locations on the Brazilian coast with the fewest works published on the es-

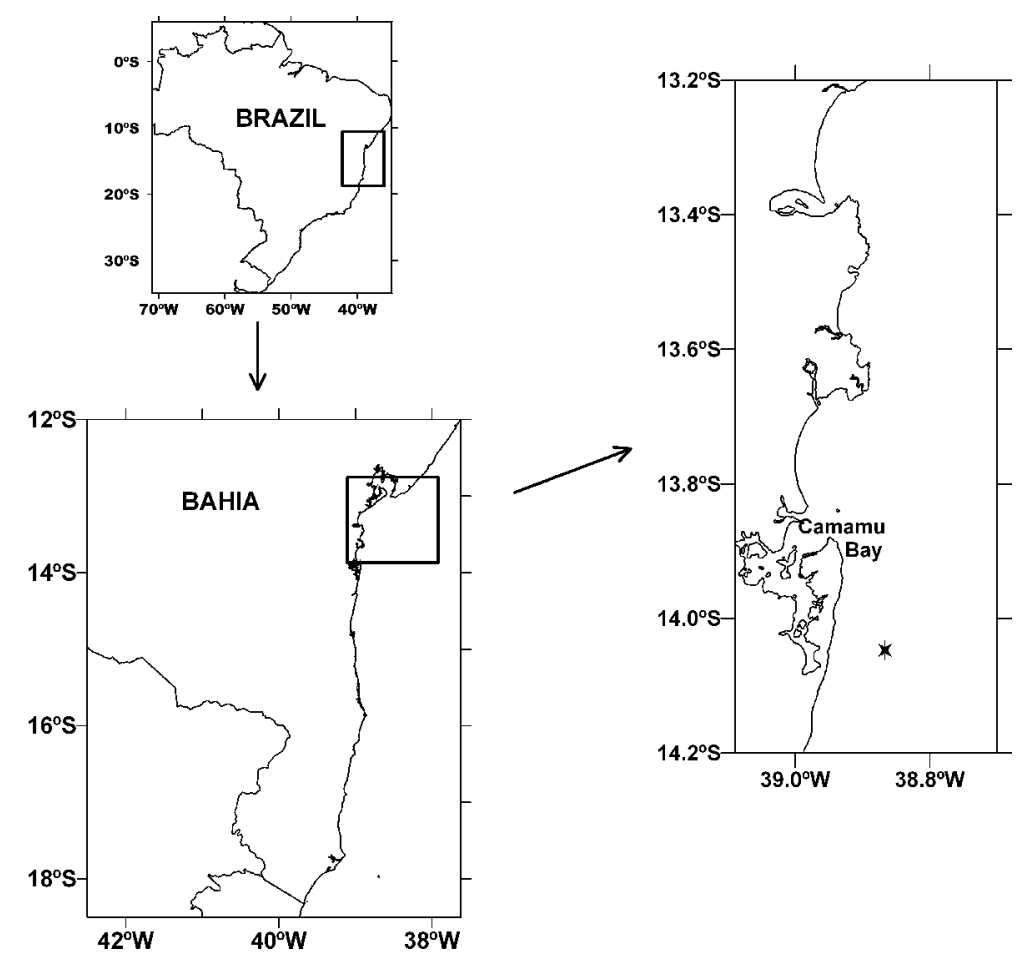

Figure 1: Map of the study area indicating the sampling stations.

http://www.biotaneotropica.org.br 
tuarine and coastal zooplankton communities (Bonecker 1995, Neumann-Leitão 1994/1995). E. paraconcinna is probably a normal, although rare, member of the local coastal zooplankton community, and has not been recorded previously because of the lack of adequate surveys. The copepod fauna of this region is similar to that found in the Gulf of Guinea (Binet \& Dessier 1971), and the occurrence of $\boldsymbol{E}$. paraconcinna in both areas reflects this similarity. This new find significantly extends its known distribution area in South America. This is only the second record in Brazilian waters; the species was previously recorded in the north of Brazil (State of Maranhão).

The three females were deposited in the copepod collection of the Integrated Zooplankton and Ichthyoplankton Laboratory (LIZI) of the Federal University of Rio de Janeiro (DZUFRJ 3244).

\section{Acknowledgements}

This study was conducted in the Integrated Zooplankton and Ichthyoplankton Laboratory, Department of Zoology, Institute of Biology, Federal University of Rio de Janeiro (UFRJ) as part of a monitoring program of Camamu Bay implemented by ENSR International do Brasil Ltda and KRITERIA Consultores Associados Ltda. We thank El Paso Óleo and Gás do Brasil Ltda for making available some of their zooplankton material for our research.

\section{References}

BINET, D. \& DESSIER, A. 1971. Premières données sur les copépodes pélagiques de la région congolaise - I. Liste des espèces et notes écologiques. Cah. O.R.S.T.O.M., sér. Océanogr., 9(4): 411-457.

BONECKER, S.L.C. 1995. Dinâmica do zooplâncton no sistema estuarino do rio Mucuri-BA. Tese de Doutorado, Universidade de São Paulo, São Paulo.

BRADFORD-GRIEVE, J.M., MARKHASEVA, E.I., ROCHA, C.E.F. \& ABIAHY, B. 1999. Copepoda. In South Atlantic Zooplankton (D. Boltovskoy, ed.). Backhuys Publishers, Leiden, v. 2, p. 869-1098.

FLEMINGER, A. 1957. New calanoid copepods of the families Aetideidae, Euchaetidae, and Stephidae from the Gulf of Mexico. Fishery Bulletin, 57(117): 355-363, pls. 1-3.

LÓPEZ-SALGADO, I., GASCA, R. \& SUÁREZ-MORALES, E. 2000. La comunidad de copépodos (Crustacea) en los giros a mesoescala en el occidente del Golfo de México (julio, 1995). Rev. Biol. Trop., 48(1):169-179.

MONTÚ, M.A. \& GLOEDEN, I.M. 1998. MaxillopodaCopepoda Marine Planktonic Calanoida. In Catalogue of Crustacea of Brazil (P.S. Young, ed.). Museu Nacional, Rio de Janeiro, p. 167-220.
NEUMANN-LEITÃO, S. 1994/1995. Resenha literária sobre zooplâncton estuarino no Brasil. Trab. Oceanogr. Univers. Fed., 23: 25-53.

PARK, T. 1975. Calanoid copepods of the family Euchaetidae from the Gulf of Mexico and western Caribbean Sea. Smithson. Contrib. Zool., 196: 1-26, Figs. 1-20.

PARK, T. 1995. Taxonomy and distribution of the marine calanoid copepod family Euchaetidae. Bull. Scripps Inst. Oceanogr. Univ. Calif., 29: 1-208.

VERVOORT, W. 1963. Pelagic Copepoda. 1. Copepoda Calanoida of the families Calanidae up to and including Euchaetidae. Atl. Rep., 7: 77-194, Figs. 1-23.

YONEDA, N.T. 1999. Diagnóstico sobre Plâncton (4. Anexo - Plâncton). Workshop para a avaliação e ações prioritárias para a conservação da biodiversidade da Zona Costeira e Marinha, 56p. http://www.anp.gov.br/ ibamaperfuracao/refere/Plâncton_Anexo.pdf (last accessed on 10/01/2006).

Title: Occurrence of Euchaeta paraconcinna Fleminger, 1957 (Crustacea, Copepoda, Calanoida) in a coastal area of Bahia State, northeastern Brazil.

Authors: Dias, C.O and Bonecker, S.L.C.

Biota Neotropica, Vol. 6 ( number 3 ): 2006

http://www.biotaneotropica.org.br/v6n3/pt/ abstract?article+bn02406032006

Date Received 08/10/2006 - Revised 09/20/2006

Accepted 10/20/2006

ISSN 1676-0611 